\title{
COURTLY PATRONAGE OF THE ANCIENT SCIENCES IN POST-CLASSICAL ISLAMIC SOCIETIES
}

\author{
EL MECENAZGO CORTESANO DE LAS CIENCIAS \\ ANTIGUAS EN LAS SOCIEDADES ISLÁMICAS \\ POST-CLÁSICAS
}

\author{
SONJA BRENTJES \\ Universidad de Sevilla
}

\begin{abstract}
In this paper I study evidence for courtly patronage for the ancient sciences in specific post-classical societies in the Arab and Persianate worlds. I show that there are plenty of historical sources for seriously challenging the widely held belief that courtly patronage for the ancient sciences disappeared in the post-classical period. I discuss similarities and differences between the classical and post-classical period at large and between specific post-classical dynasties in particular. I ask which disciplines courts sponsored, which products they privileged and which institutions and norms they used and mobilized for and through their patronage. I compare the relationship between patronage for scholars in two main settings - the court and the madrasa. I suggest that the proposed causal link between the disappearance or decrease of courtly patronage and the so-called decline of the ancient sciences needs to be revisited.
\end{abstract}

Key words: Courtly patronage; Post-classical societies; Ancient sciences.

\begin{abstract}
Este artículo estudia el mecenazgo cortesano de las ciencias de los antiguos en determinadas sociedades post-clásicas del ámbito cultural árabe y persa. El autor muestra que un gran número de fuentes históricas cuestionan la idea, muy extendida, de que ese mecenazgo desapareciera en las sociedades post-clásicas, y analiza a ese respecto las similitudes y las diferencias entre los períodos clásico y post-clásico en general, y entre distintas dinastías del período post-clásico en particular. Indaga también qué disciplinas y resultados financió y favoreció ese mecenazgo, y a través de qué instituciones y normas se ejerció, comparando sus dos principales escenarios: la corte y la madrasa. Como conclusión, sugiere que la hipótesis de que la desaparición o el debilitamiento del mecenazgo causaron el llamado declive de las ciencias de los antiguos debe ser revisada.
\end{abstract}

Palabras clave: mecenazgo cortesano; sociedades post-clásicas; ciencias de los antiguos.

Historians of science, medicine and philosophy in Islamic societies will agree without hesitation that courtly patronage was of extraordinary importance for the introduction, spread and maintenance of the ancient sciences, as well as for the many new results that scholars achieved in these fields in different Islamic societies. Despite this generally held conviction, there are no studies of the phenomenon and its various forms in specific Islamic societies. A second conviction, 
albeit less firmly held, is the belief that one of the major factors that led to what is usually called the decline of the ancient sciences was the disappearance of courtly patronage at some unclear point in time. ${ }^{1}$ This vagueness results from disagreement about when the decline commenced, and from a lack of clear statements about when courtly patronage ended. Opinions on the matter vary greatly, some seeing the eleventh century as the starting point, others the fifteenth or sixteenth century. ${ }^{2}$ Given the importance of these historiographical problems it is surprising that very little research has been done assessing the evidence for the disappearance of courtly support for all or some of the ancient sciences, and the link between this phenomenon (if it indeed can be shown to have happened) and changes in the content and innovative power of research that occurred in later Islamic societies.

In this paper I will focus on courtly patronage of the ancient sciences after 1200 in the territories between Egypt and India. I will show that courtly patronage of the ancient sciences did not disappear in this post-classical period. Several dynasties extended their support to scholars interested in a variety of ancient sciences. Such a claim finds clear substantiation in dedications and ownership marks attested in manuscripts; notes appearing in biographical dictionaries and historical chronicles about scholars at courts and their contacts with rulers, princes, emirs, viziers, other court officials and powerful women at courts; and courtly protocol and official honorific titles specified in administrative sources. The more challenging problems arise from the limitations of these materials and the need for non-trivial interpretations of the information they offer. Since courtly patronage continued

${ }^{1}$ See for instance Makdisi, G., The Rise of Colleges: Institutions of Learning in Islam and the West, Edinburgh, 1981, 77-78.

${ }^{2}$ For the various positions on the issue of decline, its date, its conceptualization, and its scope see for instance Sayll, A., The Observatory in Islam and its Place in the General History of the Observatory, Ankara, 1960, 402-429; al-Hassan, A.Y., Factors behind the Decline of Islamic Science after the Sixteenth Century, accessible on-line in the personal Website of the author: http://www.history-science-technology.com/Articles/articles\%208.htm (15-08-08); Saliba, G., Islamic Science and the Making of the European Renaissance, Cambridge, 2007; Sabra, A.I., "The Appropriation and Subsequent Naturalization of Greek Science in Medieval Islam," History of Science, 25 (1968), 223-243; Abdalla, M., The Fate of Islamic Science Between the Eleventh and Sixteenth Centuries: A Critical Study of Scholarship from Ibn Khaldun to the Present, accessible on-line in the "Australian Digital Theses Program": http://www4.gu.edu.au:8080/adt-root/public/adt-QGU20040618.091027/index.html (15-08-08), 95-141.

Al-Qanțara (AQ) XXIX 2, julio-diciembre 2008, pp. 403-436 ISSN 0211-3589 
after 1200 under several major and minor dynasties, the changes in scientific activities and the decrease in new results cannot be ascribed to lacking "state" support as such. The changes themselves, their character, scope, disciplinary, spatial and temporal occurrences as well as the modes in which they appear and the values they reflect, will not be discussed here. Neither will I offer suggestions about the factors contributing to such changes. All this goes far beyond the purpose and possibilities of this paper. But even more important, these issues are deeply steeped in prejudices and assumptions characteristic of scientific activities in our own days. There are no in-depth studies of specific cases that contextualize such changes in the value system of their times and places. In addition, the rigorous questioning of the assumptions underlying our judgments and of the suitability of our methods has only begun recently.

I use the term "ancient sciences" in this paper as a shorthand for the mathematical sciences (geometry, number theory, arithmetic, algebra, magic squares, mathematical cosmography and geography, astronomical handbooks, ephemerides, time-keeping and related issues), medicine, philosophy (metaphysics, logic, natural philosophy, economics, ethics, politics) and the occult sciences (astrology, alchemy, geomancy, numerology and related fields). The reason for doing this is that the use of the term "science" suggests a modern understanding and excludes medicine, philosophy and the occult sciences, while the use of the term "rational sciences" would exclude the mathematical sciences and include important religious disciplines such as ușül al-dìn, which I will not explore here. I will focus primarily, however, on the mathematical sciences and medicine, touching upon philosophy and the occult sciences, excluding astrology, only in a cursory manner. The reason for this limitation is found on the one hand in the lack of systematic surveys on the history of philosophy under most of the dynasties I will discuss in this paper (exceptions are the Safavids and the Mughals), and on the other in the fact that my research interests focus primarily on the mathematical sciences with some additional interest in a social history of medicine. 


\section{Courtly patronage of the ancient sciences in the classical period $^{3}$}

Courtly patronage of the ancient sciences in the classical period took place both in the form of personal relationships between a patron and a client and as an outgrowth of relations of loyalty between families. According to Mottahedeh, loyalties were the result of three cultural activities: providing benefits, concluding various types of formal commitment (oaths, vows, guarantees of safe conduct) and showing gratitude. Benefits ( $n i$ ' $m a$ ) given by a ruler to his subjects served to create stable, reciprocal ties. Generosity (samāha the ruler when handing out benefits, but when combined with indulgence (musämaha) could diminish the ruler's reputation. ${ }^{4}$ Formal commitments regulated "duties and obligations that could be enforced without coercion." 5 Practitioners of the ancient sciences benefitted from the second type of formal commitment, the vow. The vow was made to God, and contained a promise to do some particular good work on the basis of a good intention. Repairs of irrigation channels and bridges, or the building of mosques and, later, madrasas, could be announced publicly in the form of such a vow. In combination with the actual work of repair or construction, the vow served to elevate the symbolic and real power of the ruler who made it. Practitioners of the mathematical sciences, in particular surveyors and muhandisün (geometers, engineers, architects), were often involved in the repair and replacement work. The recipient of benefits was obliged to show gratitude (shukr al-ni' ma), since masculine honor was based on acknowledging received benefits, reinforced by the Qur'ān's repeated reminder that the (true) believer is grateful for God's continuous benefits. 6

Mottahedeh argued that patronage during Buyid rule resulted from this triangular net of benefits, formal commitments and gratitude. ${ }^{7}$ In

3 This part is an abbreviated extract from a larger paper on patronage of the mathematical sciences in Islamic societies, to appear in Robson, E. and Stedall, J. (eds.), The Oxford Handbook of the History of Mathematics, Oxford, forthcoming.

${ }^{4}$ Mottahedeh, R., Loyalty and Leadership in an Early Islamic Society, Princeton, 1980, 90-91.

5 Ibidem, 43.

${ }^{6}$ Ibid., $72-76$.

7 Ibid., 42.

Al-Qanțara (AQ) XXIX 2, julio-diciembre 2008, pp. 403-436 ISSN 0211-3589 
exchange for promotion, a patron expected his protégé to serve him in various ways as long as either of the two lived. ${ }^{8}$ Many of the scholars who worked as astrologers or physicians at Buyid and other courts of the period stayed until they died in courtly service, often through the reign of more than one ruler. It is no exaggeration to claim that many of the most productive and innovative astronomers/astrologers, physicians and philosophers spent long years in courtly service. This means that the impressive results of nearly five centuries of mathematical, medical and philosophical research and teaching were produced through the institution of patronage at its major centres, namely, central and local courts.

The patronage relationships that rulers, viziers and other courtiers maintained with physicians, astronomers/astrologers and philosophers were discussed in a variety of terms. A patron extended honor (ikrām) and benefits, often in a generous manner, to the men who healed him, cast his horoscope or observed the stars. The physicians and occasionally also the astronomers/astrologers are said to have served (khadama) their patrons, often until their patrons' death. Honor paid to a client could take many forms, including precious robes, monetary gifts, privileged ranking in seating at court during official occasions, and inclusion in caliphs', sultans' or viziers' groups of boon companions (nadim). Patrons also shared other more personal favors with their clients.

The scholars engaged in patronage relationships were expected to offer expertise in areas such as healing, observing the planets and stars, casting horoscopes, constructing instruments, writing books, making automata or repairing clocks, water wheels, channels, and other infrastructural components. An important professional service of physicians and astrologers was to accompany their patrons on military campaigns, pilgrimages, and other travels. Teaching sons of rulers, their relatives, and other courtiers was another service scholars of the mathematical sciences provided for their patrons. Scholars of all disciplines dedicated books and instruments to patrons from the early Abbasid period. It is, of course, not always clear whether the dedication was an expression of gratitude for benefits received or a proposal to enter into a patronage relationship. The vocabulary used in histo-

8 Ibid., 82-84.

Al-Qanțara (AQ) XXIX 2, julio-diciembre 2008, pp. 403-436 ISSN 0211-3589 
ries of scholars and bibliographies includes translating, writing, composing or doing a work for a ruler, a vizier or a scholar. Instruments as well as texts were named after patrons and designed specifically for them. ${ }^{9}$

Other ways of talking about patronage relationships in the ancient sciences included terms like ittasala bi (to be bound to, to be connected with), ghuläm (boy, youth, military slave, servant), hamala (to carry), a 'zama (to invite), 'azzaza (to elevate, to exalt, to make dear), irtabata (to bind, to commit, to engage), istakhdama (to hire, to engage the service), istahdara (to summon, to fetch), ishtāqa ila (to covet, to desire ardently), haziya inda (to enjoy the favors, to be in the good graces) and $d a a^{\prime} \bar{a}$ (to summon, to call, to urge, to invite). ${ }^{10}$ Some of these expressions, such as irtabața, istakhdama and da' $\bar{a}$, were applied to both rulers and viziers, while others such as hamala were used only of rulers. Irtabața, istakhdama and da' $\bar{a}$ describe relationships in which power, although asymmetric, is shared because not only did scholars look for patrons, but rulers and viziers likewise tried to attract clients to their courts, occasionally going to great lengths to do so. But scholars did not always accept the prospective patron's offers, invitations or gifts. The Saljuq sultan Sanjar (r. 511-582/ 1117-1157) sent the enormous sum of 1,000 dinars to 'Abd al-Raḥmān Khāzinī (fifth/twelfth century), a freed slave of Byzantine origin. Khāzini refused to take the money, saying that he possessed ten dinars, three of which sufficed to finance him for a year, plus a cat. He also rejected the same sizable monetary gift when it was offered by the wife of one of the Saljuq emirs. ${ }^{11}$

The term hamala reflects the often violent nature of medieval society and the role of scholars as pawns in conflicts between rulers, invaders, rebels, and other claimants to power. When Sebügtegin (d. 387/997) and his son Mahmūd (r. 388-421/998-1030) conquered parts of Central Asia and Iran, they forced numerous scholars to flee westwards into the protection of the Buyid dynasty, or else carried them away to Ghazna. Among those who had to relocate after the fi-

9 Charette, F., "The Locales of Islamic Astronomical Instrumentation," History of Science, 44 (2006), 123-138, 133, tables 2a, 2b.

10 This list is by no means exhaustive.

11 Al-Bayhaqī, Zāhir al-Dīn, Tārīkh ḥukamā’ al-Islām, M.Ḥ. Muḥammad (ed.), Cairo, 1996/1417, 181 .

Al-Qanțara (AQ) XXIX 2, julio-diciembre 2008, pp. 403-436 ISSN 0211-3589 
nal campaign in 408/1017 were the scientist Abū Rayhạn Bīrūnī (363-440?/973-1048?) and the physician Abū 1-Khayr al-Hasan. ${ }^{12}$ The Ghaznavids were not the only dynasty that forced scholars into their patronage. Various Khwarazmshahs brought scholars to their court in this manner, as did some dynasties in the post-classical period such as the Mongols in the thirteenth century and Timur (r. 771807/1369-1404) and his family in the late fourteenth to fifteenth centuries. ${ }^{13}$

The historical sources paint a complex and rich picture of different forms and styles of patronage. Successful relationships that lasted a lifetime are found, as are those of a more fluid nature. Cases of stability over two or even three successive rulers occurred at several courts during this period. However, cases of conflict and failed continuation of patronage were far from exceptional. Important factors in the fluidity of courtly patronage included enmity among members of the patron's family and towards his clients, as well as military, economic, and political instability. Competition among different factions within a ruling family and among families of administrators, and the growing influence of the Turkish military slaves upon the choice of the next caliph made patronage an unreliable field of social relations. As a result the figure of the itinerant, and often impoverished, scholar emerged. The asymmetry of power and the inherent instability of this imbalance are reflected in the various forms of punishment that a patron could heap on a client, either on his own behalf or on the behalf of another client. Extortion, loss of office and property, exile, imprisonment, and execution were widespread means of regulating access to power and funds among the civil elites, in particular on the level of viziers and their immediate entourage. Scholars of the mathematical sciences, even those who were powerful patrons in their own rights, also suffered under the arbitrariness of the patronage system. Several were exiled, incarcerated or killed.

Boundaries that separated patronage from other kinds of relationships, for instance those that existed in the realm of craftsmanship, are often blurred due to a lack of precise information in the sources. Ibn al-Nadìm (d. 383/993) used the term ghulām, which in the tenth

12 Ibidem, 36; Matvievskaya, G.P. and Rozenfel'd, B.A., Matematiki $i$ astronomy musul'manskogo srednevekov'ya i ich trudy (VIII-XVII vv.), Moscow, 2, 264.

13 Al-Bayhaqī, Tārīkh, 36, 173.

Al-Qanțara (AQ) XXIX 2, julio-diciembre 2008, pp. 403-436 ISSN 0211-3589 
century primarily meant a military slave, to describe relationships involving scholars of the mathematical sciences and instrument makers. In most cases, the owner or master of a ghuläm was either an astrologer or an instrument maker. Instrument makers like Ahmad and Muhammad, the sons of Khalaf (third/ninth century), often started their career as ghilmān (plural of ghulām) and later had ghilmān themselves. Both brothers had been ghilmān of the astrolabe maker 'Alī b. 'Îsā (third/ninth century) and then trained six other men as their ghilmān, all of whom became known as instrument makers. ${ }^{14}$ Hence it is perhaps reasonable to interpret this relationship as one between a master and an apprentice rather than one of patronage.

\section{Courtly patronage of ancient sciences in the post-classical period}

Courtly patronage of ancient sciences in the post-classical period was characterized by two kinds of relationships to the classical period. On the one hand, it was institutionally similar to that of the classical period; on the other, it differed in two respects profoundly from the previous period. It was institutionally similar insofar as it took place first and foremost as a relationship between individuals. Rulers supported scholars, not disciplines, even if certain forms used for installing and legalizing patronage such as waqf (religious donation) apply an abstract, disciplinary rhetoric either with specifications for individuals or without. Rulers who decided to donate professorships for certain ancient sciences, in particular medicine, often did so because of a personal experience of need. In some cases, a vow made at an earlier moment of need preceded such a donation. Scholars praised rulers, not dynasties, in dedications and inscriptions. Historians, if they talked at all about activities relating to the ancient sciences, also mentioned them only in relationship to individual rulers, members of ruling families or courtiers. Hence when I speak in this paper of courtly or princely patronage, it is important to recall this individual character of patronage relationships. It is very rare that a dynasty as a whole or even only its heads followed one single, coherent approach towards the ancient sciences and their practitioners. The most that can

14 Tajaddod, R. (ed.), Kitāb al-fihrist li-l-Nadìm, Tehran, 2nd ed., s.d., 343.

Al-Qanțara (AQ) XXIX 2, julio-diciembre 2008, pp. 403-436 ISSN 0211-3589 
be said in such rare cases is that several members of a dynasty supported a similar set of authors and texts and used them for similar purposes. The fact that the authors or texts that were patronized by various dynasties belonged to a limited number of disciplines, in particular medicine, astrology and to some extent magic, tends often to obscure the differences between individual rulers and other courtly patrons.

In the post-classical period, the rhetoric used for negotiating and representing patronage relationships lost much of its earlier richness. It shrank mainly to the three concepts of honor or grace, benefit and service. Most of the patronage relationships between an Ayyubid ruler or prince and a physician, for instance, were described using this terminology. ${ }^{15}$ The rhetoric of patronage under the Mamluks continued to revolve around the same terms as in the Ayyubid period. Clients linked themselves with and served specific patrons, and these patrons honored or benefited them. ${ }^{16}$ New terms such as qarrara $h u$ or $f i$ (to appoint s.o. to, place s.o. in), istaqarra bi (to settle down, to take a permanent place of living, i.e. a permanent position) and ikhtașa bi (to devote or dedicate an honor or service, to privilege s.o., to make s.o. special) reflect the demands and opportunities created by the system of endowed teaching institutes. Outside the Ayyubid-Mamluk domains, the impact of the endowed teaching institutes took longer to permeate the language of patronage. The continued importance of the courtly sphere for patronage of the ancient sciences in these other regions is reflected in the vocabulary used to describe relationships between patron and client. In addition to the prevalent rhetoric of service, honor and benefit, other terms like ittasala bi (to be bound to, to be connected with), nasaba (to link, to bring into relation) or ta 'alaqqa (to be attached, to be dependent, to be devoted, to be connected, to belong) were used. They expressed the fact that a patron and a client were connected or bound to each other. ${ }^{17}$

These shifts in rhetoric point to the institutional differences that separate patronage activities during the post-classical period from

15 Ibn Abī Ușaybī'a, 'Uyūn al-anbā' fì țabaqāt al-aṭibbā', N. Riḍā (ed.), Beirut, s.d., 584-6, 589-91, 598-601, 635-7 et passim.

16 Al-Sakhāwī, Shams al-Dīn, al-Daw' al-lāmi ' fì ahl al-qarn al-tāsi ', Beirut, s.d., 3, $296 ; 6,112,235 ; 8,191 ; 9,15 ; 10,48$.

17 Ibn al-Fuwațī, Talkhịs majma 'al-ādāb fì mu jam al-alqāb, M. Jawād (ed.), Damascus, 1962-1965, 4, pt.1, 40, 132, 149; pt. 2, 513, 754; pt. 3, 513. 
those of the classical period. The reason for these differences can be found primarily in two changes that occurred in regard to the social loci available for the practice of patronage and the scientific disciplines. After Nizām al-Mulk (1018-1092) made the creation of endowed teaching institutes a component of Saljuq cultural politics in the eleventh century, rulers, princes and powerful women of the Zangids, Ayyubids, Artuqids and other Sunni dynasties followed the Saljuq example in the twelfth century in northern Iraq, Anatolia, Syria and Egypt. This opened new domains for patronage outside the courtly sphere. However, in Saljuq times the courts remained major, if not the main social spaces for patronage of the ancient sciences, as suggested by the case of 'Abd al-Razzāq al-Jazarī's (d. after 603/1206) work at the Artuqid court in Diyar Bakr or the presence of physicians in the entourage of the Atabeg Nūr al-Dīn Mahmūd b. Zangi (r. 541-569/1146-1173). From the last decades of the thirteenth century onwards, princely patronage for madrasas, mosques and Sufi $k h \bar{a} n q \bar{a} h \mathrm{~s}$ with their prescriptions for teaching posts, stipends and other positions, among them the post of a muwaqqit, were features that repeatedly occurred in the cultural politics of Mamluk sultans in Egypt and Syria. As is well known, Sultan al-Manșūr Qalāwūn (r. 678-689/1279-1290), Sultan Làjīn (r. 696-98/1296-99) and Sultan al-Mu'ayyad Shaykh (815-824/1412-1421) donated hospitals and chairs for teaching medicine at mosques and madrasas in Cairo and Damascus. ${ }^{18}$ Sultan Hasan (r. 748-752 and 755-762/1347-1351 and 1354-1361) provided for a professor and six stipends in 'ilm al-mīqāt (the astronomical discipline for determining prayer times, the directions of prayer towards the Ka'ba in Mecca and the rise of the new moon as well as teaching the relevant geometrical, arithmetical, astronomical and instrumental knowledge) at his newly erected madrasa in Cairo. Other Mamluk sultans granted scholars of the ancient sciences professorial posts and posts as muwaqqits or physicians at mosques, madrasas and khānqāhs. Under the Mamluks, the social space of princely patronage shifted significantly. It moved from the courtly sphere to the sphere of the endowed teaching institutes and the hospitals. Only medicine with its offices of $r a$ ' $\bar{s}$ al-atibb $\bar{a}$ ' (head of the physicians) and the courtly diwañ remained embedded directly

18 Behrens-Abouseif, D., Islamic Architecture in Cairo, Leiden, 1989, 138-140.

Al-Qanțara (AQ) XXIX 2, julio-diciembre 2008, pp. 403-436 ISSN 0211-3589 
in the courtly sphere. The extent to which the Mamluks shifted their patronage from the court to the madrasa and hospital seems to be unique. No other dynasty in the Arab world, Anatolia, Iran, Central Asia or India established its patronage of the ancient sciences primarily outside the courtly sphere.

The Ottomans followed a mixed heritage by taking up at first examples set by the Saljuqs, the Rum-Saljuqs and other Turkic rulers in Anatolia. After the fifteenth century they also added components of Mamluk policy. As a result, they sponsored the ancient sciences within the courtly sphere, in particular medicine and astrology. Court physicians and court astrologers lived in the palace and were presided over by a head physician or head astrologer, two official courtly positions. The Ottomans also exercised a substantial amount of patronage outside the court within the realm of the endowed teaching institutes and hospitals. They sponsored hospitals, chairs for medicine at madrasas, the teaching of several mathematical disciplines and the post of the muwaqqit. Most of the major mosques in Istanbul, Edirne and Bursa provided for such a post, and the large madrasa complexes often included a hospital and a position for teaching medicine.

The proliferation of endowed teaching institutes altered the landscape of princely, but also of urban patronage in several ways. Teaching became a profession which guaranteed a stable income from the properties attached to the teaching institute. Once a client had been appointed to a position at a certain institute, regular visits with the patron were not necessary to assure funding. In this sense, the relationship became more distant and formal. However, the substantial regular income and the social prestige linked to major endowed institutes, in particular those endowed by rulers, their relatives, high ranking military leaders and major administrative officials, induced many professors to try to grab as many chairs as possible and to determine their own successors. This desire for chairs, money and influence resulted in all sorts of fights and trickery as these clients sought to defeat competitors and push colleagues from their posts. Patrons were now especially valuable to them for their capacity to offer protection against rivals from their own ranks and to support claims in case an official court complaint became necessary. In this sense, the relationship between patron and client became more intense. It could assume criminal aspects, a feature that occurred in the classical period primarily among the major secretarial families. Such criminal aspects 
consisted mainly in activities undertaken to force an office holder out of his office, mostly a professorship at a madrasa and cognate teaching institute. They comprised spreading rumours, raising false accusations, ambushing, enforcing legal persecutions or cancelling an appointment by a governor or another official who formally was not responsible for the particular waqf (donation) and its stipulations.

The bonds created between patron and client depended on opportunities and circumstances, and thus varied not only among the dynasties, but among individual members of a given dynasty and the cities where they ruled. A rare case of an astrologer affiliated in customary Mamluk style to Sultan al-Manșūr Qalāwūn was Ibrāhīm Hāsib al-Malikī al-Manșūrī in the thirteenth century. His name indicates that he was a member of the sultan's household, perhaps even a man of the sultan's personal troops. He wrote one of the very rare astrological treatises composed in Mamluk times and territories. The sources Ibrāhim claims to have used show his familiarity with the leading ninth- and tenth-century writers on the subject, among them Abu Ma'shar (d. 273/886), Ya'qūb b. Isḥāq al-Kindī (d. ca. 260/873) and Abū Sa‘īd Sijzī (ca. 334-ca. 411/ca. 945-ca. 1020). ${ }^{19}$

Timurids exercised a variety of patronage forms. For instance, in some cases they forced their patronage on unwilling clients who had been bound to weaker patrons through foster parent relationships characteristic of the slave armies of other dynasties, and exercised their princely prerogatives in regard to scholarly matters. Enforced patronage occurred mainly in the context of military conquest. Princely interference into scholarly matters took place via dismissals of office holders and occasionally through visits of classes. In other situations Timurid princes took a less aggressive approach, stimulating competition between clients and raising intellectual challenges for them.

In 789/1387, when Timur stormed the Muzaffarid stronghold in Shiraz, he forced Sayyid Sharīf Jurjānī (741-816/1340-1413) to leave the city for Samarkand and to accept him as his new patron. Jurjānī apparently did not like this new arrangement, although he could not avoid it. But once Timur died, Jurjānī left Samarkand and returned to

19 Fihrist-i kitābhā-yi khatțī-yi Kitābkhāna-yi Millī-yi Malik dābiste be-Āstān-i Quds Riżavī, vol. 1, Kitābhāayi 'arabì wa-turkī, I. Afshār and M. Taqī Dānish Pažūh (eds.), Tehran, 1352h., 1, 644.

Al-Qanțara (AQ) XXIX 2, julio-diciembre 2008, pp. 403-436 ISSN 0211-3589 
Shiraz. Ulugh Beg (r. 850-853/1447-1449) established different relationships with the scholars with whom he collaborated. He interfered in the scholarly prerogatives of Qāżīzāde Rūmī (d. 815/1412) as head of the madrasa Ulugh Beg had opened. But when Qāżīzāde Rūmī began a strike of disobedience in which he remained at home and refused to continue classes at school, Ulugh Beg inquired about what had elicited his strong response. The scholar told him that he would not work at a madrasa where someone other than the professors themselves decided what would be taught. According to Tashköprüzade (d. 969/1560), who transmitted this story, Ulugh Beg apologized and reinstated a teacher whom he had dismissed for his lack of mathematical knowledge. ${ }^{20}$ While the Timurid prince clearly appreciated Qāżīzāde Rūmī as a scholar and a man, he disliked Ghiyāth al-Dīn Kāshī's (d. 833/1429) manners who apparently failed to comply with the rules of courtly etiquette and courtesy. He teased other scholars by sending them pages with mathematical problems which he asked them to solve. ${ }^{21}$ 'Alī Qushjī (d. 879/1474), whom he took under his wing as a young boy and provided with excellent education at his madrasa, was treated like a foster son, according to reports by later historians. ${ }^{22}$ The academic knowledge that 'Alī Qushjī acquired in Samarkand and the expertise he obtained by running the madrasa and the observation program after Kāshī's death endowed him with a reputation and status that made him an honored guest in the eyes of the Aq Koyunlu ruler Üzūn Hasan (r. 871-883/14661478) and the Ottoman sultan Mehmet Fatih (r. 855-886/ 1451-1481), who invited him to courtly sessions of scholarly debate and conviviality. ${ }^{23}$

20 Tasköprüzade, A.E., Es-Saqa'iq en-No'manijje, O. Rescher (transl.), Osnabrück, 1978,8 .

${ }^{21}$ Rijāl-i Kitāb-i Habīb al-Siyar az jumle-yi mughūl tā marg-i Shāh-i Ismā 'ìl-i avval, 'A. Navā'î̀ (ed.), Tehran, 1324h., 111-112.

22 Ibidem, 122-23.

23 Osmanl Matematik Literatürü Tarihi (History of Mathematical Literature During the Ottoman Period), Istanbul, 2001, 1, 26-28.

Al-Qanțara (AQ) XXIX 2, julio-diciembre 2008, pp. 403-436 ISSN 0211-3589 


\section{Differences and similarities between princely patronage patterns in the post-classical period}

The possibility that anyone with sufficient funds could donate them for a pious purpose and open a teaching institute diminished the central role of princely patronage and created a broader spectrum of patronage opportunities outside the courts. The attitudes of rulers and their family members, as well as other members of the courtly sphere, towards continued support of scholars beyond endowing teaching institutes varied across different regions and periods. The personal entourages of many Ayyubid princes included scholars, among them physicians, geomancers, engineers and astrologers, with whom the princes spent time in meetings of debate and conviviality. Mamluk sultans and heads of Mamluk households invited scholars of the religious disciplines to sessions for reading the Qur'ān or hadith collections. Scholars of the mathematical and occult sciences were called when a Mamluk needed explanations of natural events, counsel for future activities, particularly battles, or help with prayer times and the direction towards Mecca. Physicians and geomancers were called in cases of disease. But the entourages of high ranking Mamluks only rarely included scholars of the ancient sciences serving for a lifetime as had been common under the Ayyubids. Mamluk patronage for the ancient sciences, as noted, focused first and foremost on the endowed teaching institutes. This focus on appointing preferred scholars to chairs at madrasas, mosques or khānqāhs included 'ilm al-mīqāt, medicine and occasionally the philosophical sciences.

Turkoman and Turco-Mongol tribal dynasties in Iran, Central Asia and India pursued patronage policies in regard to the ancient sciences that resembled those of the Ayyubids. Courtly support among the Injus, Aq Koyunlus and Timurids for the ancient sciences seems to have focused primarily on scholars attached to the court. Support for scholars pursuing the ancient sciences at madrasas is presently known only as the exception to this rule. The Mughals and Safavids also confined most of their patronage activity to their courts. But in contrast to the other three dynasties, they also supported scholars at madrasas, including those with an interest in the ancient sciences. Dynasties of other ethnic and social origins, such as the Muzaffarids in southern Iran, sponsored scholars within the sphere of the courts and with positions at endowed teaching institutes. Thus, although all of these Turkoman and 
Turco-Mongol dynasties adopted what is generally termed Persianate culture, this culture did not produce uniform patronage patterns. Hence other factors need to be taken into consideration, among them specific beliefs and policies intended to justify and ensure the dynasty's rule and power. For the time being, the data I could collect are insufficient to draw explanatory links between these patterns and other factors for the Injus and the Aq Koyunlus. For the Timurids, art historians have shown that Timur's politics of legitimizing himself as heir to Chingizid rule shaped most of his military and cultural decisions. ${ }^{24}$ In my view, Timurid interest in astrology, astronomical handbooks and planetary theory are similarly situated within this framework of justification. Timurid rulers and princes showed a particular interest in astronomical and astrological texts written by scholars who had worked at Ilkhanid courts. Several Timurids collected such texts and copied them for their libraries. At least three Timurid princes, if not more, also studied these texts. In many respects, Mughal patronage patterns continued the policies of their relatives, but incorporated additional elements, in particular with regard to the mathematical sciences, under the direct influence of scholars from Shiraz.

Other differences in the patronage patterns between the mentioned dynasties concern the relationship between the ancient sciences and the arts. When produced for an Inju, Timurid, Mughal, Safavid or Ottoman ruler, prince, governor, eunuch or other member of the courtly sphere, mathematical, astronomical, astrological, medical and philosophical texts were often carefully executed and finely illustrated with shamses, sarlawhs, 'unwans, gilded frames, calligraphic writings and in some cases even illuminated with miniatures and other paintings. ${ }^{25}$ Such luxury books became objects of collection and display, and found themselves in the libraries of various rulers, their officials, wives or other relatives. Preferred texts for illustration or illu-

${ }^{24}$ Lentz, T.W. and Lowry, G.D., Timur and the Princely Vision: Persian Art and Culture in the Fifteenth Century, Los Angeles, 1989; Golombek, L. and Subtelny, M. (eds.), Timurid Art and Culture: Iran and Central Asia in the Fifteenth Century, Leiden, 1992.

${ }_{25}$ Art historians who have worked on manuscripts with scientific content have focused primarily on the artistic aspects of their illumination and illustration, but rarely discuss aspects of patronage for the sciences these texts teach. Those who tried to include some reflections on the relevance of the scientific content have usually relied on secondary sources rather than on an analysis of the content and context of the texts themselves. Because of these differences in interest and focus I have abstained from citing the studies of Qazvīnī's, Suufî's and other authors' works by contemporary art historians. 
mination were 'Abd al-Rahmān Șūfî's (290-375/903-986) Kitāb suwar al-kawākib al-thābita (from now on called Star Catalogue), Zakariyyā' b. Muhammad Qazvīnī's (599-682/1203-1282) 'Ajā'ib al-makhlūqāt and Dioscorides' (first century) Materia Medica. Șūfì's Star Catalogue was repeatedly copied in the Safavid period in particular, but copies were also produced at Timurid and Mughal courts as well as at the courts of other Indian Islamic dynasties. ${ }^{26}$ Qazvīnī's cosmography was copied by artists either in its Arabic versions or in its Persian or Ottoman Turkish translations at the courts of the Injus, Jalayirids, Aq Koyunlus, Timurids, in the environment of the Safavid, Mughal and Ottoman courts and under dynasties in the Deccan. ${ }^{27}$ Such activities took place in specific locations, not always necessarily in the capital of a dynasty. The Jalayirids and Aq Koyunlus, for instance, asked for copies of Qazvinī's work primarily in Baghdad. The Jalayirids also ordered a copy of the earlier work by Salmān Ṭūsī (sixth/twelfth century) with a similar title and similar content, although more literary than scientific, but written in Persian. ${ }^{28}$ This suggests that centres of painting experience and the availability of qualified painters were decisive factors for the illustration of scientific manuscripts. The fact that Salmān Ṭūsī's work, Dioscorides' Materia Medica and other scientific texts were illustrated and illuminated in Safavid Shiraz in the sixteenth and seventeenth centuries reinforces this claim. ${ }^{29}$ However, as more manuscripts come to light

${ }^{26}$ Examples are MSS Paris, BnF, Arabe 4670, Iran, eleventh/seventeenth century; Arabe 6528, Gujarat, 1053/1643-4; Supplément persan 1551, Iran, late tenth/sixteenth century; Welch, A., Collection of Islamic Art, Geneva, 1972, 2, 69-70, mid-eleventh/mid-seventeenth century.

27 Examples are MSS Cambridge, University Library, Nn. 3.74, 974/1566; Dublin, Chester Beatty 2/2, 952/1545; Istanbul, Topkap1 Saray1, R 1660, Rabī' I 824/March 1421; London, British Library, Add. 23564, Shiraz, 845/1441, Or. 12220, Herat 910/1503-04; Manchester, John Rylands Library, Persian 2, 1029/1619, Persian 3, 1041/1632, Persian 37, ca. 1440; New York, Metropolitan Museum of the Arts, 34.109 (frontispiece of Istanbul, Topkap1 Saray1, R 1660; Paris, BnF, Smith-Lesouëf (oriental) 221; Supplément persan 334, second quarter ninth/second quarter fifteenth century, in the style of Shiraz; Supplément persan 2051, ca. 885/1480, Shiraz; Rampur, The Raza Library, A 4600, 923-4/1571-2 and A 4601, 1001/1591-2; Welch, Collection of Islamic Art, 1, 122, five pages of a late ninth/fifteenth-century manuscript; Robinson, B.W., Persian Painting in the John Rylands Library: A Descriptive Catalogue, London, 1980, 35, 273-290, 295-312, 351; Cagman, F. and Tanınd1, Z., Islamic Miniature Painting, Istanbul, 1979, 20-21.

${ }_{28}$ MS Paris, BnF, Supplément persan 332, 790/1388.

${ }^{29}$ MS Paris, BnF, Supplément persan 332, beginning of the tenth/beginning of the sixteenth century.

Al-Qanțara (AQ) XXIX 2, julio-diciembre 2008, pp. 403-436 ISSN 0211-3589 
and are carefully studied, our knowledge of where, when and for whom scientific manuscripts were illustrated and illuminated will continue to expand.

Another important factor that determined the kind of manuscripts that were copied and illustrated was the image a ruler or prince wished to portray. The stories told about Ulugh Beg or Iskandar Sultān (r. 811-818/1409-1414), for instance, suggest that they wanted to project the image of a scientifically educated prince. Hence they invested money, manpower and time in the production of high-quality illustrated copies of scientific texts for their libraries and for their personal use.

Professionally decorated manuscripts made in Iran or India include astronomical handbooks such as the Ilkhanid Tables and Zijj-i Jadīd-i Gurgānī, works on planetary theory such as Shams al-Dīn Khafrī's (d. 957/1550) al-Takmila fì l-tadhkira, Ibn Sīnā's (d. 430/1037) philosophical and medical encyclopedias Kitāb al-shifa and al-Qānūn fì l-țibb, medical writings of other authors, books on theoretical geometry such as Euclid's Elements, geographical works such as Abū Isḥāq Ibrāhīm b. Muḥammad Isțakhrī's (d. ca. 340/951) al-Masālik wa-l-mamālik, treatises on astrology and works of mixed content. Mostly, the painters and calligraphers remained anonymous as did the recipients of the manuscripts. In a few cases, either some or all of this information is given. Examples are a manuscript of Ibn Sinnā's Kitāab al-shifä' that was written and illustrated for the Ottoman sultan Mehmet III (r. 1003-1012/1595-1603) and two manuscripts of the Persian translation of Șūfì's Star Catalogue made by the court astrologer Hasan b. Sa'd Qā'inī for the governor of Mashhad Abū 1-Fath Manūchihr (d. 1045/1636). ${ }^{30}$

In contrast, Zangid, Ayyubid and Mamluk illustrated or illuminated scientific manuscripts are less numerous and cover a much smaller spectrum of themes and titles. Mechanics, natural history, astrology, medicine, the art of war and a broadly construed knowledge of horses and other useful animals were their main domains. At least one Zangid copy of Dioscorides' Materia Medica is preserved in Istanbul. ${ }^{31}$ Copies of al-Jazarī's book on automata are extant from the

${ }^{30}$ Fihrist-i kitābhā-yi khațtī-yi Kitābkhāna-yi Millī-yi Malik dābiste be-Āstān-i Quds Riżavi, 1, 463-464.

31 MS Istanbul, Topkap1 Saray1, Ahmet III 2127, 626/1228.

Al-Qanțara (AQ) XXIX 2, julio-diciembre 2008, pp. 403-436 ISSN 0211-3589 
Mamluk period, as are copies of Qazvīnī's 'Ajā'ib al-makhlūqāt and Sūfî's Star Catalogue. ${ }^{32}$ Several illuminated manuscripts on horses reflect Mamluk experience with Mongol war tactics that posed a grave challenge to Mamluk cavalry. ${ }^{33}$ Other texts sponsored by Mamluk sultans dealt with curing sick horses and the diseases of other animals. ${ }^{34}$ Such texts show that Mamluk patronage of the ancient sciences and related knowledge did not include scholars only, but extended to members of their army and their stables. In addition, there exist single copies from the Mamluk period of each of the following: a work on war machines for the Ayyubid Salāh al-Dīn (r. 564-589/1169-1193), Abū Ma'shar's Kitāb al-mawālìd, Isțakhrīs al-Masālik wa-l-mamālik and Ibn al-Durayhim's (712-761/13121360) Kitāb manāfi 'al-hayawān. ${ }^{35}$

Another difference between the post-classical dynasties that sponsored the ancient sciences at their courts or through their endowment of teaching institutes concerns the disciplines that were privileged. In most cases, the only way to determine which disciplines were favored at court is to collect information about dedicated texts, instruments and other material objects such as medical bowls, amulets or miniatures. Although such dedications do not necessarily reflect the interests and tastes of the dynasties and their courts, they indicate at least perceptions among scholars, instrument makers and other craftsmen about what kind of discipline could expect an open ear and a friendly gesture. Zangid and Ayyubid princes received sundials, globes and

32 Welch, Collection of Islamic Art, 1, 28-32; MS Paris, BnF, Arabe 2490, 922/1516; Attl, E., Art of the Arab World, Washington, 1975, 102-114.

33 See for instance Muhammad b. 'İsā al-Āqsarā'̄'s's (d. 749/1348) Nihāyat al-su'l, in a copy produced in Mamluk Syria or Egypt in 1371, MS London, British Library, Add. 18866. Another work of this genre of furüsiyya is Muhammad b. Ya'qūb ibn Khazzām al-Khuttalī's (eight/fourteenth century) Kitāb al-makhzūn fì jämi ' al-funūn. See De Bagdad à Ispahan: Manuscrits islamiques de la filiale de Saint-Pétersbourg de l'Institut d'Études Orientales, Académie des Sciences de Russie, Musée du Petit Palais, 14 octobre 1994-8 janvier 1995, Lugano-Paris-Milan, 1995, 170-176.

${ }^{34}$ An example is Abū Bakr b. Badr (or: Mundhir) al-Bayțār's (d. 741/1340-1) Kāmil al-șinā'atayn. MS Bursa, Kharājčì Oghlu, n. ${ }^{\circ} 1122$.

${ }_{35}$ MSS Paris, BnF, Arabe 2583; London, British Library, Or. 5305; Escorial, Ar. 898; Ruiz Bravo-Villasante, C., El Libro de las utilidades de los animales de Ibn al-Durayhim al-Mawsili, Madrid, 1981. There are several other illustrated or illuminated scientific manuscripts that are either not dated or do not mention the place of their production, which are ascribed by art historians to Ayyubid or Mamluk Syria or Egypt. For a debate on Mamluk illustrated and illuminated manuscripts see Atıl, E., "Mamluk Painting in the Late Fifteenth Century," Muqarnas, 2 (1984), 159-171.

Al-Qanțara (AQ) XXIX 2, julio-diciembre 2008, pp. 403-436 ISSN 0211-3589 
medical bowls with magic squares and incantations, some of which are obvious fakes. ${ }^{36}$ Șalāh al-Dīn also received medical treatises and the aforementioned work on war machines. One of the Ayyubid viziers, Ibn al-Qifți (d. 646/1248), was the recipient of a work on toponyms and other geographical information. ${ }^{37}$

Thanks to Ibn Abī Ușaybī'a's (592-670/1194-1270) dictionary on physicians and other scholars of the ancient sciences, our knowledge about Ayyubid patronage of these sciences is comparatively better than that of other Islamic dynasties in the same period. ${ }^{38}$ As Ibn Abi Ușaybī'a's book proves, Ayyubid rulers enjoyed surrounding themselves with several physicians to whom they were often linked for a lifetime. In many cases a court physician only moved to the next Ayyubid court after a patron had died. In contrast, Ayyubid rulers did not consider astrologers a necessary scholarly group at their courts. Only a minority of Ayyubid princes patronized astrologers. Those who did apparently did not employ more than one astrologer at a time.

More interest seems to have existed for philosophical debates at the courts in Hama and Damascus. In the first decades of the thirteenth century, scholars with strong interests in logic, metaphysics and kalām fought at Mu'azzam 'İsā's (r. 615-624/1218-1227) court in Damascus about Ibn Sīnā's philosophical heritage and Fakhr al-Dīn Rāzī's (544-606/1149-1209) evaluation of this oeuvre. Sayf al-Dīn al-Āmidī (d. 631/1233), who had been a client of the prince in Hama until the latter's death, received an invitation to come to the Damascene court. There he excelled through his intelligence and eloquence. ${ }^{39}$ His strong self-esteem brought him many enemies, among them Shams al-Dīn Khusrawshāhī (d. 652/1254), his rival in the rational sciences and the teacher of Mu'azzam 'İsā's son and successor Nāṣir al-Dīn Dā'ūd (r. 624-626/1227-1228), but more importantly Ibn al-Șalāḥ al-Shahrazūrī (577-643/1181-1245), one of the leading

36 Savage-Smith, E. and Maddison, F., Science, Tools \& Magic, London, 1997.

37 Fihrist-i kitābhā-yi khațtī-yi Kitābkhāna-yi Milli-yi Malik dābiste be-Āstān-i Quds Riżavī, 1, 698.

${ }^{38}$ Somewhat surprisingly, Ibn al-Qiftī has little to say about Ayyubid patronage of the ancient sciences in his dictionary.

39 Brentjes, S., "Orthodoxy", Ancient Sciences, Power, and the Madrasa ("College”) in Ayyubid and Early Mamluk Damascus, Berlin, 1997, Preprint 77, 23, footnote $67 ; 24$, footnote $70 ; 27$, footnote 76 . 
scholars of hadith and a sworn opponent of logic, which he had unsuccessfully studied with Kamāl al-Dīn ibn Yūnus (d. 640/1242) in Mosul. In addition to alienating leading 'ulamā' in Damascus, Sayf al-Dīn apparently also violated some of the rules of patronage by allowing the ruler of Amid, his native town, to negotiate with him about leaving Ayyubid patronage without actually taking up the offer. When the beleaguered lord of Amid answered a taunt by the head of the Ayyubid family al-Kāmil (r. 615-635/1218-1238), which asserted that he had no scholar worth his name in his town, with the proud rebuke that Sayf al-Din had accepted his offer to become the town's new chief judge, the scholar's fate was sealed. Al-Kāmil's brother al-Ashraf (r. 626-635/1228-1237), who had conquered Damascus one year after his brother Mu'azzam 'İsā's death and forced his nephew al-Nāșir to leave for the fortress town Karak together with his teacher Khusrawshāhī and his physician Ibn Abī Ușaybī'a, had developed a deep dislike for Sayf al-Dīn. After the confrontation involving Amid, he dismissed the scholar from his chair at the 'Aziziyya madrasa, according to a claim akin to that of Sibt b. al-Jawzī (d. 654/1256): "Him who teaches something other than tafsir and fiqh and turns to the doctrine of the philosophers I will expel." 40 Although it is not known whether al-Ashraf asked Ibn al-Salāh for legal support, the scholar backed in principle the ruler's breach of patronage conduct when he issued a fatwā against teaching any other discipline but hadith, tafsìr and fiqh. ${ }^{41}$ However, al-Ashraf surrounded himself with other scholars of the ancient sciences, some of whom he explicitly invited to join his entourage. ${ }^{42}$ This is one of the reasons why I read the story of Sayf al-Dīn's dismissal by al-Ashraf primarily as a story of conflicts in patronage relationships between a brilliant and self-confident scholar, his peers and his patrons. ${ }^{43}$

40 Ibidem, 23.

41 Ibid., 18. For a brief summary of the traditional reading of Sayf al-Dìn's house arrest see for instance Madelung, W., "The Search for God's Law: Islamic Jurisprudence in the Writings of Sayf al-Dīn al-Āmidī by Bernard G. Weiss," Islamic Law and Society, 4 (1997), 122-125, 122.

42 Brentjes, "Orthodoxy", 24, footnote 69.

43 There are other points that support seeing Sayf al-Dīn's repeated troubles as resulting directly from his breach of courtly etiquette. Sibt b. al-Jawzī, for instance, told a story of Sayf al-Dīn angering Mu'azzam 'İsā by coming too late to a session and not showing his respect to the ruler. This indiscretion allegedly induced Sibt b. al-Jawzī to interfere in favor of his colleague. See Brentjes, "Orthodoxy", 23, footnote 67.

Al-Qanțara (AQ) XXIX 2, julio-diciembre 2008, pp. 403-436 ISSN 0211-3589 
In contrast, philosophy was not a discipline that attracted much interest among the Timurids. First and foremost, they patronized history and geography, which traditionally were not considered scientific disciplines, except for mathematical geography. ${ }^{44}$ Above and beyond this focus on history and geography that occupied an important position in Timurid self-representation, astrology and astronomy drew most of their attention. The casting of horoscopes was a regular component in Timurid intellectual culture. Iskandar Sultān and Ulugh Beg patronized astronomy, geometry and arithmetic. The observatory and madrasa for the mathematical sciences built by order of Ulugh Beg in Samarkand are well known, as are the anthologies composed at Iskandar Sulțān's courts in Shiraz and Isfahan. Several of the surviving manuscripts from Iskandar Sultān's courts contain scientific treatises on astrology, astronomy, geometry, mathematical geography, alchemy and medicine.

Several Timurid rulers and princes, beginning with Timur himself, were dedicatees of texts which included scientific topics or were exclusively devoted to one of the ancient sciences. Some manuscripts of a Persian translation of the Rasā'il ikhwān al-safä' contain a dedication to Timur. ${ }^{45}$ After the death of Iskandar Sultān, Ghiyāth al-Dīn Kāshī, who had worked at his court in Shiraz and written several astronomical texts for the prince, dedicated at least two of his mathematical works to his new patron Ulugh Beg. Other important collaborators in the program of astronomical observations patronized by the Timurid prince also dedicated works to him, but in contrast to Kāshī's treatises, the texts dedicated by Qāżīzāde Rūmī and 'Alī Qushjī to Ulugh Beg were of an elementary nature. The overall pattern of such texts in the mathematical sciences seems to be that Zijjes, surveys and introductions were considered appropriate either as offers to Timurid rulers and princes in search of patronage, or as expressions of appreciation and gratitude for received support and benefits. Also belonging to this group are the texts dedicated to Abū 1-Qāsim Bābur Bahādur Khān (r. 851-862/1447-1457) and Abū Sa'īd Gürägān (r. in

44 Ettinghausen, R., "An Illuminated Manuscript of Hafiz-i Abru in Istanbul," Kunst des Orients, 1 (1959), 30-44; Soudavar, A., Art of the Persian Courts, New York, 1992, 62-5; Ferrier, R.W. (ed.), The Arts of Persia, New Haven \& London, 1989, 205-206.

${ }^{45}$ Fihrist-i nuskhahāa-yi khațtīi-yi kitābkhāna-yi Imām-i Sāadiq-i Qazvīn, M. Ṭāyār Marāghī (ed.), Qazvīn, 1378, 1, 225-226, n. ${ }^{\circ} 190$.

Al-Qanțara (AQ) XXIX 2, julio-diciembre 2008, pp. 403-436 ISSN 0211-3589 
Samarqand 855-863/1451-1459 and Herat 864-874/1459-1469). In addition to writings on the mathematical sciences, astronomical instruments also were dedicated to Ulugh Beg.

Medicine and mineralogy were among the other disciplines considered by scholars to be worthwhile subjects for the production of treatises dedicated to Timurid rulers and princes. The well-known and often-copied anatomical work Tashrīh al-badan by Manșūr b. Muhammad b. Ahmad (fl. ca. 794/1390) was dedicated by its author to Pīr Muhammad Bahādur Khān (807-809/1404-1406); the commentary on Najīb al-Dīn Muhammad b. 'Alī Samarqandī's (d. 618/1221) al-Asbāb wa-l-'alāmāt by Burhān al-Dīn Nafīs Kirmānī (fl. 841/1437-8) was dedicated to Ulugh Beg; and the Jawāhir-nāme by Zayn b. Hâjjjī was dedicated to Shāhrukh (r. 808-851/1405-1447). ${ }^{46}$

As indicated earlier, Mamluk sultans and emirs primarily supported 'ilm al-miqāt, medicine and furüsiyya (the knowledge of horses and the art of cavalry). Some also patronized astrology and geomancy, but there was no official position for an astrologer or geomancer at court. The wealthy and powerful Mamluk Amīr Yashbak min Mahdī al-Dawādār (d. 885/1480) commissioned a treatise on geomancy. ${ }^{47}$ As with veterinary medicine and cavalry, Mamluk sultans paid special attention to administrative practice. For instance, in 850/1446-7 Sultan Qaytbāy (873-901/1468-1495) received a treatise, written in beautiful thulth, on the fiscal year, its relation to the lunar calendar and its use in official documents. ${ }^{48}$ An exceptional case in the Mamluk period was that of the Ayyubid scholar-prince Abū l-Fidā', the governor of Hama. As is well known, he wrote his own substantial works on mathematical geography and history. In 710/1310-11 he also commissioned a commentary by 'Umar b. Dā'ūd b. Sulaymān al-Fārisī (fl. ca. 710/1310-11) on Naṣīr al-Dīn Tūsī's Tadhkira, which discusses planetary theory. ${ }^{49}$

The Jalayirids and the Aq Koyunlu supported music, considered part of the mathematical sciences, as well as mineralogy, natural his-

${ }^{46}$ Fihrist-i nuskhahā-yi khațtī-yi Kitābkhāna-yi 'Umūmī-yi Āyatullāh al-'Uzmā Mar 'ashī Najafí, Qom, 12, 1315sh, 144, n. ${ }^{\circ} 4569 ; 14,1366 \mathrm{sh}, 148,{ }^{\circ}{ }^{\circ}$ 5364; Fihrist-i nuskhahā-yi khațīi-yi kitābkhāna-yi Imām-i Sāadiq-i Qazvīn, 1, 151, n. ${ }^{\circ} 117$.

${ }^{47}$ MS Dublin, Chester Beatty, n. ${ }^{\circ} 3120$.

${ }^{48}$ King, D.A., A Survey of the Scientific Manuscripts in the Egyptian National Library, Cairo, 77, C 83.

49 Ibidem, 60, C21.

Al-Qanțara (AQ) XXIX 2, julio-diciembre 2008, pp. 403-436 ISSN 0211-3589 
tory and philosophy. Manuscripts dedicated to rulers of these two dynasties include the Jawāhir-nāme by one Muhammad b. Manșūr for Hasan Bahādur Khān (Ūzūn Hasan) and his son Khalīl Bahādur Sultān, and two works dedicated to Ya'qūb Bahādur Khān (r. 884896/1479-1490): Khwāja Fażl Allāh b. Rūzbehān Khunjī Iṣfahānī’s (ninth/fifteenth century) Persian translation of the philosophical story of Ḥayy b. Yaqzāan, and Idrīs b. Husām al-Dīn Munshī's Rabī $a l-a b r \overline{a r}$, in which he debated the natural properties of each season. ${ }^{50}$ A single text on geometry, Ilhāq b. A. Ishāà's commentary on Naṣīr al-Dīn TTūsì's edition of Euclid's Elements, was dedicated to this same Aq Koyunlu ruler in 886-7/1481-2. ${ }^{51}$ The connection of Jalāl al-Dīn Davvānī (830-907 or 8/1426-1501 or 2) first with Timurid, then with Aq Koyunlu rulers is well known. He dedicated several of his writings on philosophy and related topics to princes of these two dynasties. ${ }^{52}$ Asked by Üzūn Hasan for commentaries on philosophical texts, he edited Nașirr al-Dīn TTūsī's ethics and wrote treatises on Shihāb al-Dīn Suhravardī's teachings. ${ }^{53}$ In 887/1482 he wrote an introduction to Ilhāq's unfinished commentary on the Elements, recommending it and expressing his hope for its speedy completion. ${ }^{54}$ Commentaries on astronomical texts, such as Ṭūsî̀ $S i$ faṣl on the compilation of ephemerides, also are attributed to Davvānī. ${ }^{55}$

The rulers of the Inju dynasty were interested in encyclopedias, astrology, medicine and magic. The Inju ruler Abū Isḥāq (r. 744-754/ 1344-1353) sponsored some of the scholars who left the Ilkhanid capital Sultaniyeh due to the upheaval and uncertainties caused by the death of Abū Sa'īd Bahādur Khān (r. 716-736/1316-1335). Muhammad b. Mahmūd Āmulī (d. ca. 753/1352) was one of these schol-

${ }^{50}$ Fihrist-i nuskhahā-yi khațtī-yi Kitābkhāna-yi 'Umūmī-yi Āyatullāh al-'Uzmā Mar'ashī Najafì, 16, 1368sh, 222, n. ${ }^{\circ} 6234 ; 19,1369$ sh, 379-380, n. ${ }^{\circ} 7574$.

${ }^{51}$ MS London, British Library, Or. 1514. Although I have not seen them, there are two other copies of this text extant in the Archaeological Museum and the Süleymaniye Library in Istanbul. Osmanl Matematik Literatürü Tarihi, 1, 31-32.

${ }^{52}$ Fihrist-i nuskhahā-yi khațīi-yi Kitābkhāna-yi 'Umūmī-yi Āyatullāh al-'Uzmā Mar'ashī Najafì, 28, 1379sh/1421, 280, n. ${ }^{\circ} 483$.

${ }_{53}$ Cooper, J., "al-Dawani, Jalal al-Din (1426-1502)," in C. Edward (ed.), Islamic Philosophy. From the Routledge Encyclopedia of Philosophy, accessible on-line in http://www.muslimphilosophy.com/ip/rep/H038.htm (15-08-08).

54 MS London, British Library, Or. 1514, ff 1a-b.

55 Fihrist-i nuskhahā-yi khațtî-yi Kitābkhāna-yi 'Umūmī-yi Āyatullāh al-'Uzmā Mar'ashī Najafì, 21, 231. 
ars. Around 741/1340, he wrote his encyclopedia of the sciences, which included substantial material on a broad range of the ancient sciences, both their so-called fundaments and their branches. A manuscript of an unidentified text on Iranian history which included numerous miniatures was produced in the environment of the Inju court in Shiraz in about 741/1340. Welch has argued that it is a Persian version of the same type of astrological history as that encountered in Māshā'allāh's (d. 200/815) and Abū Sa'īd Sijzī’s Arabic works. ${ }^{56}$

The Muzaffarids exhibited interest in the same fields as the rival Injus, and apparently also in geography. They began as a local dynasty in Maybud, starting with Mubāriz al-Dīn Muhammad (r. 713-759/1313-1357). In 748/1347, a geographical work with the classical title Suwar al-aqālìm was dedicated to him in Yazd. In 754/1353, Mubāriz al-Dīn conquered Shiraz. His son Shāh Shujā' (r. 759-786/1357-1384) patronized 'Alī b. Muhammad al-Sayyid al-Sharīf Jurjānī (741-816/1340-1413), whom he appointed in $778 / 1377$ to a teaching position at the Dār al-Shifä́ ' in Shiraz. Jurjānī wrote a commentary on an epitome of the Elements, a copy of which is extant in Mashhad. ${ }^{57} \mathrm{He}$ may also have been the author of an encyclopedia called Maqālìd al-'ulüm fì l-hudūd wa-l-rusüm, a copy of which is extant at the British Library. ${ }^{58}$ It is dedicated to Shāh Shujā' Shāh Shujā's need for magical support is indicated by a mirror with magic squares and other formulas that was dedicated to him in Muharram 777/June 1375. ${ }^{59}$

Safavids, Ottomans and Mughals sponsored astrology and medicine by establishing regular courtly offices for their practitioners. The majority of texts on the ancient sciences dedicated to Safavid rulers, princes, governors and viziers fall into these two disciplines. They include surveys on diseases and remedies, discussions of the properties of individual remedies, ephemerides, horoscopes and surveys of astrological themes and methods. ${ }^{60}$ Characteristic of Safavid interest in medicine is the apparently widespread incorporation of magic in the

56 Welch, Collection of Islamic Art, 3, 42.

57 Matvievskaya and Rozenfel'd, Matematiki, 2, 476.

58 MS London, British Library, Or. 3143.

59 Soudavar, Art of the Persian Courts, 46-47.

60 See, for instance, Tourkin, S., "The Horoscope of Shah Tahmāsp," in J. Thompson and Sh.R. Canby (eds.), Hunt for Paradise: Court Arts of Safavid Iran 1501-1576, Milan, 2003, 327-331.

Al-Qanțara (AQ) XXIX 2, julio-diciembre 2008, pp. 403-436 ISSN 0211-3589 
form of engraved bowls. ${ }^{61}$ In addition to these two disciplines, works on astronomical instruments, in particular the astrolabe, on star constellations, arithmetic, geometry, geomancy, $f a \bar{l}$ (an art of prognostication) and philosophy were either dedicated to or commissioned by Safavid courtly patrons, in particular the shahs 'Abbās I (r. 985-1038/ 1587-1629), ‘Abbās II (r. 1052-1077/1642-1666), Sulaymān (r. 10771105/1667-1694) and Husayn (r. 1105-1135/1694-1722). ${ }^{62}$

An important element in Safavid patronage of the ancient sciences was their interest in and support for translations of Arabic texts into Persian. In the course of the seventeenth century, several Arabic medical, geographical and astronomical texts were translated at Safavid courts in Isfahan and Mashhad, among them Abū l-Fidā's (672732/1273-1331) Taqwìm al-buldān, 'Abd al-Raḥmān Șūfîs Star Catalogue and Ibn Jazla's (d. 495/1100) Taqwìm al-abdän. The Safavid reputation for having scientific works translated from Arabic into Persian is emphasized by the ascription of the translation of Abū l-Fidā's work to Khalīfa Sulțān (d. 1064/1653), a son-in-law of 'Abbās I and great vizier to three Safavid rulers, who is said in some manuscripts to have translated the geography on Safi's (r. 1038-1052/1629-1642) order in 1050/1640. ${ }^{63}$ In addition to scientific works, Ibn al-Qifți's history of scholars of the ancient sciences was also translated into Persian for a Safavid shah, namely Sulaymān. ${ }^{64}$

Mughal rulers and princes, in particular Akbar (r. 963-1014/ 1556-1605), Jahāngīr (r. 1014-1037/1605-1627), Shāh Jahān (r. 10371068/1628-1658) and Dārā Shikūh (1025-1069/1615-1659), patronized the translation of Sanskrit mathematical, astronomical, philosophical and religious works into Persian. In 995-6/1587 the poet

61 See Savage-Smith, E., "Safavid Magic Bowls," in Thompson and Canby (eds.), Hunt for Paradise, 241-247.

62 For a survey on mathematical, astronomical and astrological works dedicated to Safavid patrons see Brentjes, S., "The Mathematical Sciences in Safavid Iran: Questions and Perspectives," in F. Speziale and D. Hermann (eds.), Intellectual Relations and the Renewal of Religious Thought in Iran and Muslim India During the Modern Period, Proceedings, Conference 30 June-2 July 2007, Tehran, forthcoming. For some of the lavishly illustrated manuscripts on $f a \bar{l}$ made for Tahmāsb see Arthur M. Sackler Gallery, Smithsonian Institution, Washington DC, S1986.253a-b, S1986.254.

${ }^{63}$ Fihrist-i kitābhā-yi khaț̣ī-yi Kitābkhāna-yi Millī-yi Malik dābiste be-Āstān-i Quds Riżavi, 2, 129.

${ }^{64}$ Ibidem, 2, 129; Fihrist nuskhahā-yi khațtī-yi farsī, A. Munzavī (ed.), Tehran, s.d., 6, 3943 .

Al-Qanțara (AQ) XXIX 2, julio-diciembre 2008, pp. 403-436 ISSN 0211-3589 
Fayżī translated Bhāskara's (d. after 1183) Lìlāvatī for Akbar. ${ }^{65}$ In about 1074-5/1663, a Hindu scholar wrote a Persian commentary on the translated text. In 1044/1634-5, 'Atā' Allāh Rashīd b. Ahmad Nadir, the eldest son of the architect of the Taj Mahal, translated Bhāskara's Bïjaganita for Shāh Jahān. ${ }^{66}$ In addition to these two mathematical texts, various Upanishads and the Mähäbhärata were translated into Persian. ${ }^{67}$

Ottoman sultans and viziers, among them Mehmet Fatih and Ahmet Fazil Köprülü (1045-1087/1635-1676), sponsored translations of scientific works from Greek into Arabic, and from Persian, Arabic, Latin, Italian and French into Ottoman Turkish. Examples are Ptolemy's, (Pseudo-)Ibn Hawqal's and Blaeu's works on geography, Qazvīnī's book on cosmography and natural history, Nașī al-Dīn Ṭūsì's little survey on the astrolabe, Čaghminnīs introduction into mathematical cosmography, works written by muwaqqits in Mamluk Egypt and Syria, as well as astronomical and astrological works mostly by French writers of the seventeenth and eighteenth centuries. Scholars responded to the changing cultural conditions at court by dedicating translations into Persian or Ottoman Turkish to sultans, viziers or religious dignitaries. This could include the translation of treatises earlier dedicated in another language to a different patron, mostly outside the Ottoman realm. Examples are 'Alī Qushjī's rededications of his introductory works on arithmetic and mathematical cosmography, first dedicated to Ulugh Beg, to Mehmet Fatih after translating them from Persian into Arabic. This practice, whereby works formerly offered to one patron were rededicated to another, also can be observed with other dynasties, and could occur with

${ }^{65}$ Winter, H.J.J. and Mirza, A., "Concerning the Persian Version of Lilavati," Journal of the Asiatic Society, 18 (1952), 1-10, 2-3.

${ }_{66}$ Catalogue of the Arabic and Persian Manuscripts in the Oriental Public Library at Bankipore, vol. IX (Persian MSS.), Philology and Sciences, M. Abdul (ed.), Patna, 1925, cc. 1112-1113; Rahman, A., Alvi, M.A., Khan Ghori, S.A. and Samba Murthy, K.V. (eds.), Science and Technology in Medieval India: A Bibliography of Source Materials in Sanskrit, Arabic and Persian, New Delhi, 1982, 391.

${ }^{67}$ Göbel-Groß, E., Sirr-i akbar: Die persische Upanișadenübersetzung des Mogulprinzen Dārā Šukoh; Eine Untersuchung der Übersetzungsmethode und Textauswahl nebst Text der Praśna-Upanișad Sanskrit-Persisch-Deutsch, Marburg, 1962; Athar Ali, M., "Translations of Sanskrit Works at Akbar's Court," Social Scientist, 20 (1992), 38-45; D'Onofrio, S., "A Persian Commentary to the Upanishads: Dara Shikoh's Sirr-i akbar," in Speziale and Hermann (eds.), Intellectual Relations.

Al-Qanțara (AQ) XXIX 2, julio-diciembre 2008, pp. 403-436 ISSN 0211-3589 
works other than translations. It reflects the difficulties arising from loss of patronage due to the death of a patron. The quantity of works translated under the Ottomans was considerable and has not yet been systematically investigated.

\section{Honors, benefits and services}

The main services scholars of the ancient sciences were expected to provide their patrons consisted of medical treatment in case of illness, preparation of remedies and drugs, casting horoscopes, determining auspicious days, compiling ephemerides and surveys on good and bad days, teaching children, and dedicating surveys, introductions and occasionally more substantive treatises on individual scientific topics to their patrons. Dedications were expected to include praise for the recipient, the specification of his titles and the expression of good wishes for his rule, health and afterlife. Loyalty, as discussed for Sayf al-Dīn al-Āmidī above, was another item a patron expected of his client. To what extent clients were expected to offer new ideas for modelling the trajectories of the planets or arguing about movement of physical bodies, or to present unique approaches to solving old problems such as the determination of the direction for prayer, is difficult to ascertain. Certain rulers, princes and viziers in the post-classical era, among them Mehmet Fatih, Iskandar Sultān, Ulugh Beg, 'Alī Shīr Navā'ì, Humāyūn, Akbar and Dārā Shikūh, however, took note of theoretical questions, received at least an introductory education in the theoretical fundaments of astronomy and asked their clients for surveys of such matters. Stories told in biographical dictionaries and historical chronicles suggest that in addition to being able to address everyday necessities, such as determining the auspicious day for a particular activity or healing a sick person, scholarly clients were expected to be conversant in all themes discussed at the endowed teaching institutes and beyond. Knowing more than was regularly taught was particularly important when visitors from other regions and countries came, displayed superior knowledge, and defeated local scholars in a munäzara. Patronized debates with strangers were akin to battles. Poor performance on the part of the local scholars could entail a loss of face, and hence of reputation, for the participating patron. Defeating a stranger, on the other 
hand, was honored by material and pecuniary rewards and could entail the start of a successful patronage relationship, with a continued rise through courtly functions and offices and an ever-increasing salary. On one occasion, in the second half of the ninth/fifteenth century, a scholar of the occult sciences from North Africa came to Istanbul. Sultan Mehmet Fatih arranged for a public disputation in his presence between the scholars of Anatolia and this visitor. The local scholars could not answer the visitor's questions about the occult sciences, which were unfamiliar to them. The sultan was very upset, since he felt he had lost face. He ordered that a scholar be found with excellent knowledge of the occult sciences. A certain Mullā Khiḍr Bey, who, despite his youth, had studied all possible disciplines and taught in a provincial town, was recommended and called to the capital. In a further disputation this Anatolian scion of the sciences managed to defeat the visitor from the West due to the latter's lack of knowledge outside the occult disciplines. The sultan was delighted, honored the young scholar greatly, appointed him to the teaching post at the madrasa founded by his grandfather in the former Ottoman capital Bursa, increased his daily salary several times and promoted him to other prestigious and profitable offices. ${ }^{68}$

The story about Mehmet Fatih and Mullā Khiḍr Bey illustrates some of the actions a patron undertook for a cherished client. He fostered the client's career through offices or incorporation into the household, protected him from rivals and other obstacles, and expressed his gratitude, appreciation and respect by means of gifts and payments. A patron needed to be generous in his rewards for services rendered, but had to avoid overtaxing his personal treasury or that of the dynasty. As Tashköprüzade's story about Ulugh Beg and Qāżīzāde Rūmī, summarized above, suggests, a patron ideally did not interfere in scholarly activities or his client's academic responsibilities. In practice, however, as Qāżīzāde Rūmī’s reply to Ulugh Beg implies, a patron did interfere more often than not. The lines of obligation became blurred when patrons were also scholars, and when scholars obtained influential offices and became powerful patrons in their own rights.

68 Tasköprüzade, Es-Saqa'iq, 54-55.

Al-Qanțara (AQ) XXIX 2, julio-diciembre 2008, pp. 403-436 ISSN 0211-3589 


\section{Court libraries}

Libraries were mostly bound to individuals, although endowed teaching institutes and particularly important shrines and mosques acquired a steadily growing number of donated manuscripts that became attached to the institute rather than to its professor(s). While the originals of dedicated works usually were destined for the library of a ruler, vizier or other member of a court, most manuscripts that filled such a court library were copied by scribes of the court's workshop, bought at markets or from owners of libraries, received as gifts or taken as booty. Various scientific manuscripts exist today that were copied explicitly for a courtly library. The following examples illustrate this point: two manuscripts of 'Abd al-Raḥmān Șūfî's Star Catalogue, in the Bibliothèque Nationale and the Library of Congress respectively, were made for Ulugh Beg's library; Isțakhrī's al-Masālik wa-l-mamālik in the British Library was made for a Mamluk patron; and 'Ayn al-Zamān Abū 'Alī b. 'Alī Marwazī's (d. 548/1153) Keyhān Shenākht in the Public Library of Āyatollāh Mar'ashī in Qom and Ulugh Beg's Zīj-i Jadīd-i Gurgānī were made for Ulugh Beg's library and are kept today in the Freer and Sackler Gallery in Washington, DC. Al-Jazarī's book on the automata was made in 755/1354 for the library of the Mamluk emir Nașr al-Dīn Muhammad b. Tulak al-Ḥasanī al-Mālikī al-Sāliḥī, and came later to the library of the Ottoman sultan Ahmet III (r. 1115-1143/1703-1730). ${ }^{69}$ Some of the more precious manuscripts such as this last work ended up on the international art markets, cut to pieces and sold to museums and private collections in the US and Europe.

Mughal, 'Adil Shahi and Ottoman rulers and other members of the court seem to have searched for and bought scientific manuscripts not only because of the fame of their authors and the importance of their content, but also because of the antiquity of a given copy and its artistic execution. A partial copy of Bīrūn̄̄'s astronomical magnum opus dedicated to the Ghaznavid Sultan Mas'ūd b. Mahmūd (r. 421-432/ 1030-1040) was acquired by a courtier of Shāh Jahān's court in 1060/1649. A copy of Ghiyāth al-Dīn Kāshī’s Miftāh al-hisāa dedicated to Ulugh Beg was bound for Tippu Sultānn's (r. 1163-1214/

69 Welch, Collection of Islamic Art, 1, 31-32; Soudavar, Art of the Persian Court, 67-9.

Al-Qanțara (AQ) XXIX 2, julio-diciembre 2008, pp. 403-436 ISSN 0211-3589 
1750-1799) library. ${ }^{70}$ Other manuscripts changed hands as a result of wars, as exemplified by a copy of Tūsī's edition of Euclid's Elements, which came from the library of Muhammad 'Ādil Shāh (r. 10351070/1626-60) in Bijapur in 1069/1659 into the library of the Mughal ruler Awrangzīb (r. 1069-118/1659-1707) after he had defeated the last 'Ādil Shāh in 1097/1686.

To some extent, it is possible to reconstruct collections of scientific works that were once in court libraries in the post-classical period. A systematic survey of ownership marks and seals in scientific manuscripts can contribute to a better understanding of courtly patronage of the ancient sciences by showing which types of texts and which authors were collected, in which times the copies were produced or, occasionally, where and from whom copies were bought or looted. A comparison of texts produced and reproduced in the lifetimes of these libraries can indicate to what extent their composition reflects the contemporary scientific life. While such a reconstruction is beyond the scope of this paper, the information provided by catalogues of the Āstān-i Quds Riżavī Library in Mashhad about the library of the Afshar ruler Nādir Shāh (1148-1160/1736-1747) will serve as an example. The biography of Nādir Shāh does not indicate whether he received in his childhood, youth or adulthood a substantive education in the intellectual traditions of his Safavid predecessors. Nevertheless, his library was rich in manuscripts, with texts on the ancient sciences as the following table shows.

${ }^{70}$ Blochet, E., Catalogue de la collection de manuscrits orientaux de M.Ch. Schefer, Paris, 1900, 87; Schöler, G., unter Mitarbeit von H.-C. Graf von Bothmer, T. Duncker Gökçen, H. Jenni, Arabische Handschriften. Teil II. Stuttgart, 1990, 172; Loth, O., A Catalogue of the Arabic Manuscripts in the Library of the India Office, London, 1877, 215-216, 220.

Al-Qanțara (AQ) XXIX 2, julio-diciembre 2008, pp. 403-436 ISSN 0211-3589 
Table 1 Scientific texts from Nādir's Library ${ }^{71}$

\begin{tabular}{|c|c|c|}
\hline Author & Title & Discipline \\
\hline ‘Abd al-Sattār b. Qāsim & Tadhkirat al-ḥukamā’ & History of scholars \\
\hline Abu l-Faṭ̣ Shahrastānī & Kitāb al-milal wa-1-niḥal & $\begin{array}{l}\text { History of philosophy } \\
\text { and religious sects }\end{array}$ \\
\hline $\begin{array}{l}\text { Hunayn b. Ishạa } \\
\text { (translator) }\end{array}$ & al-Mu‘ālajāt al-buqrāṭyya & Medicine \\
\hline ‘Alī b. ‘'̄sā Kamāl & Tadhkirat al-kaḥhālīn & Ophthalmology \\
\hline $\begin{array}{l}\text { Muhammad b. } \\
\text { Zakariyyā' Rāzī }\end{array}$ & Mufīd al-khāṣṣ & Medicine \\
\hline Ibn Sīnā & al-Qānūn ${ }^{72}$ & Medicine \\
\hline Ibn Sīnā & al-Qānūn & Medicine \\
\hline Ibn Sīnā & al-Qānūn & Medicine \\
\hline \multirow[t]{3}{*}{ Fakhr al-Dīn Rāzī } & Sharh al-Qānūn & Medicine \\
\hline & Dustūr-i sākhtan-i tiryāq & Pharmacy \\
\hline & Dhakhīre-yi Iskandariyye & Medicine \\
\hline $\begin{array}{l}\text { Ismā‘īl b. Husayn } \\
\text { Jurjānī }\end{array}$ & $\begin{array}{l}\text { Dhakhīre-yi } \\
\text { Khwārazmshāhī }\end{array}$ & Medicine \\
\hline \multirow[t]{2}{*}{ Ibn Nafîs al-Qurashī } & Sharḥ al-Qānūn & Medicine \\
\hline & Miftāḥ al-khazā'in & Medicine \\
\hline Abū Yazīd Șahār Bakht & Sharḥ-i Kunnāsh & Medicine \\
\hline $\begin{array}{l}\text { Husayn b. Bistām } \\
\text { Wāsițī }\end{array}$ & Ṭibb al-a'imma & Medicine \\
\hline
\end{tabular}

${ }^{71}$ I ordered the titles as taken from the catalogues according to disciplinary affiliations starting with two books on history of scholars and beliefs followed by medical, mathematical, occult and philosophical sciences according to the understanding of the period.

${ }^{72}$ The three manuscripts mentioned here contain different parts of the work.

Al-Qanțara (AQ) XXIX 2, julio-diciembre 2008, pp. 403-436 ISSN 0211-3589 


\begin{tabular}{|c|c|c|}
\hline Author & Title & Discipline \\
\hline Abū 1-Fidā' & Taqwīm al-buldān & $\begin{array}{l}\text { Mathematical } \\
\text { geography }\end{array}$ \\
\hline Ḥusām al-Dīn Sālār & $\begin{array}{l}\text { Risāle dar istikhrāj-i samt-i } \\
\text { qibla }\end{array}$ & $\begin{array}{l}\text { Mathematical } \\
\text { geography }\end{array}$ \\
\hline Ḥusām al-Dīn Sālār & $\begin{array}{l}\text { al-Risāla fi l-khuṭūt al-mu- } \\
\text { tawāziya }\end{array}$ & Geometry \\
\hline 'Abdallāh Ḥāsib & al-Fawā'id al-Bahā'iyya & Arithmetic \\
\hline \multirow[t]{2}{*}{ Nașīr al-Dīn Ṭūsī } & Hisāb & Arithmetic \\
\hline & Manẓūme dar riyāżī & Mathematics \\
\hline Sayyid Sharīf Jurjānī & Sharh-i Tadhkira & Astronomy \\
\hline Niẓām al-Dīn Birjandī & Sharḥ-i Bīst bāb & Astronomy \\
\hline Bahā’ al-Dīn 'Āmilī & Risāle dar asțurlāb & Astronomy \\
\hline Abū Ma'shar & al-Madkhal & Astrology \\
\hline $\begin{array}{l}\text { 'Alī Shāh Muhammad } \\
\text { Khwārazmī }\end{array}$ & Risāle-yi tasyīrāt-i nujūmī & Astrology \\
\hline \multirow[t]{2}{*}{ Husayn Wā'iz Kāshifĩ } & Lavā'iḥ al-qamar & Astrology \\
\hline & Fālnāme & Occult Science \\
\hline Aristotle (ascribed) & al-Samā’ wa-l-'ālam & Natural philosophy \\
\hline Ibn Sīnā & al-Shifä' & Philosophy \\
\hline Qāżī Sirāj al-Dīn & Lațā'if al-ḥikma & Philosophy \\
\hline Nașīr al-Dīn Ṭūsī & $\begin{array}{l}\text { Risāle dar ṣudūr-i mavjūdāt } \\
\text { az mabda }\end{array}$ & Philosophy \\
\hline Mubārak Shāh Bukhārī & Sharḥ-i Hikmat al-'ayn & Philosophy \\
\hline Qāżī Hụsayn Maybudī & Sharḥ Hidāyat al-ḥikma & Philosophy \\
\hline $\begin{array}{l}\text { Shams al-Dīn Mạ̣mūd } \\
\text { Iṣfahānī }\end{array}$ & Sharḥ-i qadīm-i Tajrīd & Metaphysics \\
\hline
\end{tabular}

Al-Qanțara (AQ) XXIX 2, julio-diciembre 2008, pp. 403-436 ISSN 0211-3589 


\begin{tabular}{|l|l|l|}
\hline \multicolumn{1}{|c|}{ Author } & \multicolumn{1}{c|}{ Title } & \multicolumn{1}{c|}{ Discipline } \\
\hline Ibn Sīnā & Manțiq, al-Shifā' & Logic \\
\hline Quṭb al-Dīn Rāzī & Sharḥ al-Shamsiyya & Logic \\
\hline Sayyid Sharīf Jurjānī & Risāle-yi Kubrā & Logic \\
\hline
\end{tabular}

The titles preserved today in Mashhad represent a puzzling mixture. Among them are books that were repeatedly copied in the tenth/sixteenth and eleventh/seventeenth centuries and most likely studied in Safavid madrasas, such as the work on arithmetic al-Fawä'id al-Bahā'iyya, Quṭ al-Dīn Rāzì's commentary on the Shamsiyya and Qāżī Husayn Maybudī's commentary on Hidāyat al-hikma. Ibn Sīnā's Kitāb al-Shifä', as well as his Qānūn, were also copied more than once and could be found in madrasas in Isfahan in the eleventh/seventeenth century. Other titles, such as al-Risāla fì l-khuțūt al-mutawäziya by Husām al-Dīn Sālār, are rarities and not known to have been part of the madrasa education in the Safavid period. Since titles such as the one on parallel lines were not only a rarity in Nādir's time, but also find no mathematical context in his library, at least insofar as it was given to Āstān-i Quds Riżavī Library, it is highly unlikely that the Afshar ruler acquired the manuscript on his own as a result of specific interest in a seventh/thirteenth-century discussion of the parallel postulate.

Because of these structural features, I suggest viewing the extant manuscripts on the ancient sciences from Nādir's library as a remainder of the library of the Safavid shahs. It must be emphasized, however, that this constitutes only a minor part of what this library may have included. With the exception of a single title, namely Bahā' al-Dīn 'Āmilī's treatise on the astrolabe, no works dedicated to a Safavid shah, and no other of Bahā' al-Dīn's mathematical and astronomical writings - so famous in the eleventh/seventeenth century in Iran, India and the Ottoman Empire - can be found among Nādir's manuscripts. This suggests not only that a substantial quantity of manuscripts once present in the palatial library were dispersed or destroyed when the Afghans sacked Isfahan in 1136/1722. It also implies that while Nādir obviously was interested in collecting a range of texts on the ancient sciences, he also was eager to present himself as an admirer of the intellectual luminaries studied in the Safavid period. 


\section{Reflections}

Patronage of the ancient sciences in post-classical Islamic societies is a field worthy of study, and rich in material evidence in both libraries and manuscripts. This paper only touches in a preliminary manner on some of the most obvious issues that patronage involved. Issues not addressed here due to a lack of data include, for instance, princely patronage of writers outside the scholarly sphere, the similarities and differences between patronage for scholars and instrument-makers, and patronage exercised by minor dynasties and courts of governors. A considerably more meticulous examination of dedications, ownership marks and other types of information would help greatly to expand and clarify the available evidence. This material could then serve as the basis for analyzing the types and forms of relationships that a patron and a client could engage in, and for understanding the specific details of patronage activities as exercised by individual patrons and clients. Applying theories from other human and social sciences would be helpful for interpreting connections between social structures, cultural rituals and the presence or absence of patronage activities relating to individual ancient sciences. As for the link between courtly patronage of the ancient sciences and their increasing loss of innovative potential, further study is needed to establish links between courts, princely education and courtly libraries, on the one hand, and madrasas, their educational profiles, public scholarly debates and the content of texts produced for a patron, in comparison with those written for students or colleagues, on the other. Once we understand more fully the similarities and differences between the intellectual atmospheres at courts and madrasas, we may be better equipped to answer which of the two social loci of the ancient sciences has contributed causally to the increasingly elementary and repetitive character of the content of newly written works in these disciplines.

Recibido: $26 / 02 / 08$

Aceptado: 05/06/08 